\title{
CERUSSITE FROM EVEN-GRAINED RAPAKIVI, SALTVIK, ÅLAND ISLANDS, SW FINLAND
}

\author{
KRISTIAN LINDQVIST and VELI SUOMINEN
}

\begin{abstract}
Bull. Geol. Soc. Finland 60, Part 1, 75-78, 1988.
Key words: cerussite, fluocerite, heavy minerals, granites, rapakivi, Åsbacka, Saltvik, Åland, Finland.
\end{abstract}

Kristian Lindqvist and Veli Suominen: Geological Survey of Finland, SF-02150 Espoo, Finland.

\section{Introduction}

During mineral separation for age determination of even-grained rapakivi granites, some rare accessory minerals were identified. In this connection fluocerite was identified from the Fjälskär granite stock in Houtskär, SW Finland (cf. Suominen 1988; Lahti and Suominen 1988). Cerussite, $\mathrm{PbCO}_{3}$, not previously described from Finland, was found in the even-grained rapakivi granite of Åsbacka, Saltvik, Åland Islands, SW Finland. This sample (age determination sample A763 of the Geological Survey of Finland) is derived from the Ödkarby intrusion in Saltvik (see Bergman 1978). Frosterus and Sederholm (1890) called the intensely red and medium-grained rock Haga granite. The modal analysis and chemical composition of the rock type have been given by Bergman (1981 and 1986).

\section{Heavy accessory minerals}

The heavy (d>3.3) minerals of the Åsbacka sample were studied under a stereo microscope and identified mainly with XRD-methods. Cerussite occurs as small $(\varnothing<0.1 \mathrm{~mm})$ anhedral to short-prismatic grains varying in colour from colourless to white and reddish yellow. Six grains of cerussite were recognized under the stereo microscope and hand-picked for further studies.

This even-grained rapakivi granite contains less zircon than the surrounding wiborgitic types of rapakivi granite. According to Nurmi and Haapala (1986), this is a common feature of evengrained rapakivi granites. The zircon crystals of the heavy fraction are colourless or yellow to brown, euhedral, tetragonal prisms.

Other minerals identified from the heavy fraction are fluocerite, black and green anatase, yellow xenotime, chalcopyrite (occasionally altered to bornite and malachite), loellingite, arsenopyrite, molybdenite, pyrite, bastnaesite and rutile.

In connection with the heavy mineral studies, two different types of fluorite were identified: one is transparent colourless to light violet with octahedral crystal habit and the other is yellowish brown and anhedral. 


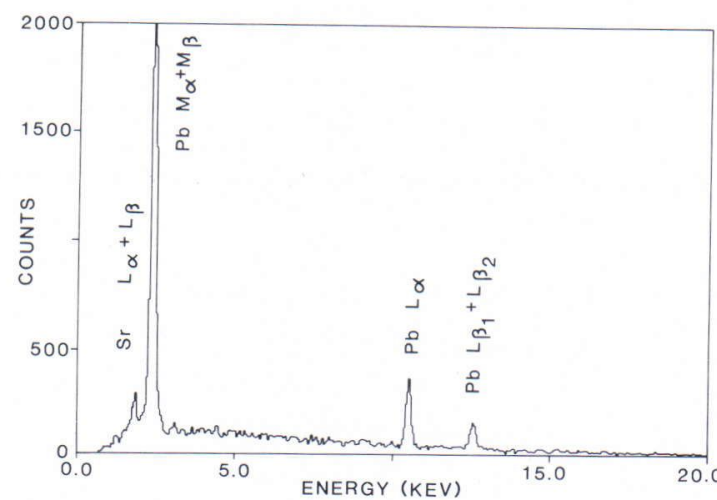

Fig. 1. Energy dispersive spectrum of cerussite from Åsbacka, Saltvik.

\section{Analytical and X-ray diffraction data on cerussite}

The energy dispersive spectrum of the Åsbacka cerussite shows only lead with traces of strontium (Fig. 1). The content of $\mathrm{Sr}$ is estimated to be about 1 weight $\%$.

$\mathrm{X}$-ray powder diffraction data obtained with the Debye-Scherrer method (camera diameter $11.46 \mathrm{~cm}$ ) are presented in Table 1 . Ni-filtered $\mathrm{Cu}$-radiation was used and silicon was mixed in as an internal standard. Due to broadened reflections and possible doublets the error of measurement has to be noted. Some of the hkl-indices of reflections with small d-values differ from those given in the JCPDS file card no. 5-417 (JCPDS; International Centre for Diffraction Data, 1986). The systematic extinctions were set according to the space group Pmen given in the above mentioned JCPDS-card (cf. group Pnma of Henry and Lonsdale 1952, p. 151). Only reflections with the hkl-indices coinciding with those given in the JCPDS card were used for unit cell calculations with the least squares method. The error in the last decimal was estimated using the relationships given by Kelsey (1964).

The unit cell dimensions seem generally to be slightly smaller than the values reported for synthetic cerussite (cf. e.g. JCPDS Mineral Powder Diffraction File 1986, p. 198: $a=5.183, \mathrm{~b}=$ 8.503 and $\mathrm{c}=6.144 \AA, \mathrm{V}=270.8 \AA^{3}$ ).
Table 1. X-ray powder diffraction data on cerussite from Åsbacka, Saltvik.

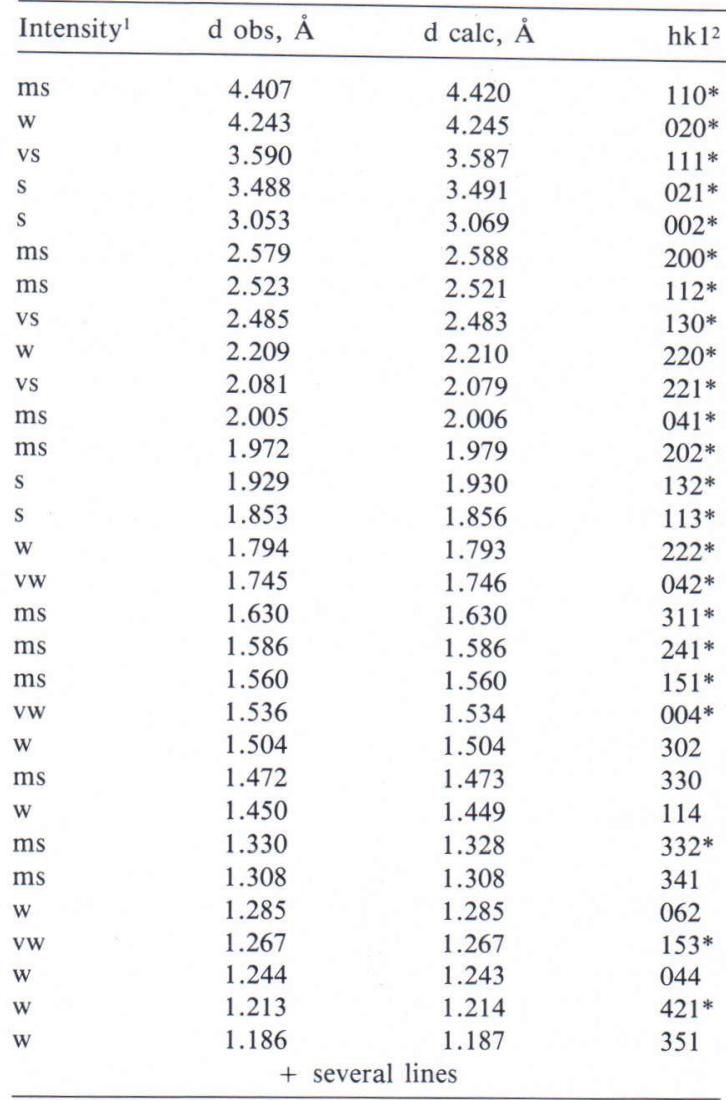

\begin{tabular}{lll}
\hline Cell dimensions & $\begin{array}{l}\text { Space } \\
\text { group }\end{array}$ & $\begin{array}{l}\text { Systematic } \\
\text { extinctions }\end{array}$ \\
$\mathrm{a}=5.177 \pm 0.004 \AA$ & Pmcn & hk1: no \\
$\mathrm{b}=8.490 \pm 0.009 \AA$ & & hk0: h+k=2n \\
$\mathrm{c}=6.137 \pm 0.004 \AA$ & & $0 \mathrm{k} 1:$ no \\
$\mathrm{V}=269.7 \AA^{3}$ & & h01: $1=2 \mathrm{n}$ \\
\hline
\end{tabular}

$$
\begin{aligned}
& \text { vs }=\text { very strong } \\
& \mathrm{s}=\text { strong } \\
& \mathrm{ms}=\text { medium strong } \\
& \mathrm{w}=\text { weak } \\
& \mathrm{vw}=\text { very weak } \\
& 2 *=\text { used for unit cell calculations }
\end{aligned}
$$

\section{Isotope composition of cerussite}

The isotope composition of lead from three tiny cerussite crystals (unwashed) was analysed and found to be: ${ }^{206} \mathrm{~Pb} /{ }^{204} \mathrm{~Pb}=21.407,{ }^{207} \mathrm{~Pb} /{ }^{204} \mathrm{~Pb}$ $=16.005$ and ${ }^{208} \mathrm{~Pb} /{ }^{204} \mathrm{~Pb}=40.302$. 


\section{Conclusions and discussion}

The slightly reduced unit cell observed is thought to be due to substitution of $\mathrm{Sr}$ for $\mathrm{Pb}$ in the cerussite lattice. Because the average interatomic distances of the $\mathrm{Sr}-\mathrm{O}$ bonds are shorter than the corresponding $\mathrm{Pb}-\mathrm{O}$ bonds in the metal-oxygen polyhedra, shrinkage of the unit cell is to be expected. According to Speer (1983), the interatomic average distances in the orthorhombic carbonates are $2.636 \AA$ for $\mathrm{Sr}-\mathrm{O}$ and $2.69 \AA$ for Pb-O. Speer (1983) attributes the differences in the lattice parameters of the orthorhombic carbonates to differences in the ionic radii of the divalent cations. However, the lattice parameters observed for the cerussite from Åsbacka are very close to the values that Sahl (1974) determined for synthetic cerussite. Speer (1983) reports the average $\mathrm{C}-\mathrm{O}$ distance in strontianite to be $1.285 \AA$, and in cerussite $1.27 \AA$. Thus the longer $\mathrm{C}-\mathrm{O}$ distances in the $\mathrm{CO}_{3}$ groups of strontianite compared to the corresponding distances in cerussite seem to compensate, at least partly, for the smaller $\mathrm{Sr}$ ion.

Chang and Brice (1972) studied the subsolidus phase relations of the aragonite-type carbonates and predicted a complete series of solid solution in the system $\mathrm{SrCO}_{3}-\mathrm{PbCO}_{3}$, at least in the temperature range $400-750^{\circ} \mathrm{C}$. On the basis of the graphs of Chang and Brice (1972), the a- and c-axes of the Åsbacka cerussite indicate a Sr content of 10 and 2 mole $\%$, respectively. The b-axis observed falls outside the range given, suggesting some uncertainty in the use of the method for determining the $\mathrm{Pb} / \mathrm{Sr}$ ratio of cerussite. An immiscibility gap in the solid solution at low temperatures would explain the discrepancies observed.

\section{References}

Bergman, L., 1978. Pre-Quaternary rocks. Sheet 1021 Geta. Geological map of Finland 1: 100000.

—, 1981. Berggrunden inom Signilskär, Mariehamn och Geta
Cerussite is regarded as a secondary mineral formed during the alteration of galena or, less commonly, other lead minerals (Speer 1983). Robinson (1974) found that cerussite from Tui Mine, New Zealand, formed as a supergene mineral at a temperature of about $30^{\circ} \mathrm{C}$. The lead isotope composition of the Ásbacka cerussite shows that a considerable amount of radiogenic lead is incorporated in the sample. Such a composition is typical of secondary minerals and proves the supergene nature of the mineral. No further estimations of the temperature of formation were made, but the very low temperature reported by Robinson (1974) from Tui Mine is thought to apply to the cerussite from Åsbacka as well.

The two types of fluorite crystals observed reflect crystallization at different stages. According to Drugman (1932), octahedral, lightcoloured fluorite is typical of granites and pegmatites. Fluorite of veins occurs as more deeply coloured cubic crystals. The latter type seems to be typical of low-temperature fluorite crystallization.

Fluocerite, now identified from two different even-grained rapakivi granites, seems to be a characteristic accessory mineral of even-grained rapakivi granites as late intrusion phases of plutons and stocks.

Acknowledgements. We are indebted to Dr. Seppo Lahti for discussions and for his comments on our draft and to Dr. Ragnar Törnroos for the energy-dispersive analysis. This paper benefitted from the comments of Dr. Martti Lehtinen. We thank Mr. Matti Sakko for analysing the lead isotope composition, and Mrs. Mirja Saarinen for helping with the mineral hand picking and XRD runs. Mrs. Gillian Häkli corrected the English of our manuscript. kartblad. Signilskärin, Maarianhaminan ja Getan karttaalueiden kallioperä. Summary: Pre-Quaternary rocks of the Signilskär, Mariehamn and Geta map-sheet areas. Ge- 
ological map of Finland 1: 100 000. Explanation to the maps of Pre-Quaternary rocks. Sheets $0034+0043,1012$ and 1021, $72 \mathrm{p}$.

- , 1986. Structure and mechanism of intrusion of postorogenic granites in the archipelago of southwestern Finland. Acta Acad. Aboensis B, Math. Phys. 46, (5), 74 p.

Chang, L. L. Y. \& Brice, W. R., 1972. Subsolidus phase relations in aragonite-type carbonates: II. The systems $\mathrm{CaCO}_{3}-\mathrm{SrCO}_{3}-\mathrm{PbCO}_{3}$ and $\mathrm{CaCO}_{3}-\mathrm{BaCO}_{3}-\mathrm{PbCO}_{3}$. Am. Mineral. 57, 155-168.

Drugman, J., 1932. Different habits of fluorite crystals. Mineral. Mag., 23, 137-144.

Frosterus, B. \& Sederholm, J. J., 1890. Beskrifning till kartbladet N:o 17. Finström. [Explanation to the geological map of Finland $1: 200$ 000], 48 p.

Henry, N. F. M. \& Lonsdale, K. 1952. International tables for X-ray crystallography. Vol. 1., Symmetry groups. The Kynoch Press, Birmingham, 558 p.

Kelsey, C. H., 1964. The calculation of errors in a least squares estimate of unit-cell dimensions. Min. Mag. 33, 809-812.

Lahti, S. I. \& Suominen, V., 1988. Occurrence, crystallography and chemistry of the fluocerite-bastanaesite- cerianite intergrowth from the Fjälskär granite, SW Finland. Bull. Geol. Soc. Finland 60, 00-00.

Nurmi, P. A. \& Haapala, I., 1986. The Proterozoic granitoids of Finland: Granite types, metallogeny and relation to crustal evolution. Bull. Geol. Soc. Finland 58, 203-233.

Robinson, B. W., 1974. The Origin of Mineralization at the Tui Mine, Te Aroha, New Zealand, in the Light of Stable Isotope Studies. Econ. Geol. 69, 910-925.

Sahl, K., 1974. Verfeinerung der Kristallstruktur von Cerussit, $\mathrm{PbCO}_{3}$. Zeitschr. Kristallogr. 139, 215-222.

Speer, I. A., 1983. Crystal chemistry and phase relations of orthorhombic carbonates. In Reeder, R. J. (ed.) Carbonates: mineralogy and chemistry. Reviews in Mineralogy, 11. Mineralogical Society of America, 394 p.

Suominen, V., 1988. (in prep.) The chronostratigraphy of southwestern Finland. With special reference to the Postjotnian and Subjotnian diabases. Geol. Survey Finland, Bull.

Received October 29, 1987

Revised and accepted January 7, 1988 